\title{
Influence of Bt-transgenic pollen, Bt-toxin and protease inhibitor (SBTI) ingestion on development of the hypopharyngeal glands in honeybees ${ }^{1}$
}

\author{
Dirk BABENDREIER $^{a *}$, Nicole M. KALBERER ${ }^{\mathrm{a}}$, Jörg RoMEIS ${ }^{\mathrm{a}}$, Peter Fluri ${ }^{\mathrm{b}}$, \\ Evan MULLIGAN ${ }^{\mathrm{c}}$, Franz BIGLER $^{\mathrm{a}}$ \\ a Agroscope FAL Reckenholz, Swiss Federal Research Station for Agroecology and Agriculture, Reckenholzstr. \\ 191, 8046 Zürich, Switzerland \\ b Agroscope ALP Liebefeld-Posieux, Swiss Federal Diary Research Station for Animal Production, Swiss Bee \\ Research Centre, Schwarzenburgstr. 161, 3003 Bern, Switzerland \\ ${ }^{\mathrm{c}}$ Institute for Research on Environment and Sustainability, University of Newcastle, UK
}

Received 29 November 2004 - revised 6 April 2005 - accepted 21 April 2005

Published online 19 October 2005

\begin{abstract}
In order to assess the risks of transgenic crops for honey bee colonies, we studied the development of hypopharyngeal glands of adult workers. We introduced 50 newly emerged adult bees into small, queenright colonies of c. 250 bees. Bees were fed either Bt-transgenic maize pollen (MON 810) or a sugar solution containing either purified Bt-toxin (Cry1Ab, 0.0014\% w/v) or Kunitz soybean trypsin inhibitor (SBTI) at two concentrations $(0.1 \%$ and $1 \% \mathrm{w} / \mathrm{v})$. Neither the Bt maize pollen nor the Bt toxin showed any effect on bee survival or on the development of hypopharyngeal glands after a period of 10 days' feeding. In contrast, treatment of newly emerged bees with SBTI $(0.1$ and $1 \%)$ for 10 days significantly reduced the mean weights of the hypopharyngeal glands and the mean diameter of the glands' acini. While small amounts of Bt toxin were detected by ELISA in the hypopharyngeal glands of bees fed the Bt-sugar solution, SBTI could not be detected in gland samples by Western blotting.
\end{abstract}

Apis mellifera / Cry1Ab / Kunitz soybean trypsin inhibitor / transgenic plants / risk assessment

\section{INTRODUCTION}

One of the major concerns related to the growing of transgenic plants in the environment is the detrimental effects that these may pose to non-target organisms (Conner et al., 2003; Dutton et al., 2003). Therefore, non-target effects have to be assessed as part of the environmental risk assessment necessary for the commercialization of transgenic crops. Due to its high ecological and economic importance the honey bee, Apis mellifera L., is regarded as one of the key species to be tested for potential effects of novel plant protection methods.
Both hazard and exposure must be considered when assessing the risk of transgenic plants to honey bees. While hazard is basically a function of the toxicity of the transgene product, exposure is dependent on several factors. Bees may be exposed to transgene products via pollen or nectar. Pollen is a bees main protein source (Crailsheim, 1990; Crailsheim et al., 1992) while nectar is known to contain mainly sugars and rather low concentrations of proteins (Baker and Baker, 1986). As the toxins produced by transgenic plants have not yet been detected in nectar (Malone and Pham-Delègue, 2001), pollen feeding is likely to be the main route of exposure.

\footnotetext{
* Corresponding author: dirk.babendreier@fal.admin.ch
}

1 Manuscript editor: Jean-Noël Tasei 
However, a marked difference exists between the exposure of adult and larval stages of the honey bee. It was recently shown that honey bee larvae consume only small amounts of pollen (Babendreier et al., 2004) while adults consume large quantities of pollen not only for their own requirements but also to provide the larvae with food (Haydak, 1970; Crailsheim et al., 1992). This food is produced in the hypopharyngeal glands which are located in the head of the worker honey bee. The development of the hypopharyngeal glands begins in young adult bees and they reach maximum weight when the bees are 6-15 days old (Crailsheim and Stolberg, 1989; Knecht and Kaatz, 1990). Correspondingly, the size of the hypopharyngeal glands' acini increases during this period and acini diameter reflects the amount of produced food proteins thus giving an indication of gland activity (Knecht and Kaatz, 1990; Hrassnigg and Crailsheim, 1998). At the age of 6-15 days, bees are generally nurse bees, taking care of the larvae in the hive until the brood cells can be sealed. Older worker bees become foragers and their hypopharyngeal glands retrogress (Fluri et al., 1982; Deseyn and Billen, 2005).

Altogether, there is a large body of literature indicating that the hypopharyngeal glands are an important aspect of bee life history and for development of the whole colony. For this reason, gland size and acini diameter have been used as indicators to test the effect of various food sources such as pollen from different plants (Standifer, 1967) or pesticides (Gupta and Chandel, 1995). As protein turnover is high in the hypopharyngeal glands, we hypothesized that feeding on transgenic protein may influence the development of these glands in young nurse bees.

The studies investigating the effects of transgenic products on honey bees have recently been reviewed by Malone and PhamDelègue (2001). While most studies recorded only bee mortality, few studies dealt with sublethal effects that may still be important for the development of a colony. An exception is a series of experiments carried out on learning behaviour by using the conditioned proboscis reflex (Picard-Nizou et al., 1997; Girard et al., 1998). Malone et al. (2004) recently studied potential effects of Cry1Ba, the biotin binding protein avidin and the protease inhibitor apro- tinin on the hypopharyngeal glands finding no significant differences.

Transgenic maize pollen containing an endotoxin (Cry1Ab) of the soil bacterium Bacillus thuringiensis (Bt) was utilised in this study. This plant was developed to control lepidopteran pest insects like the European corn borer, Ostrinia nubilialis (Koziel et al., 1993). Exposure of honey bees to maize pollen can be considerable contributing up to $20 \%$ of the total amount of pollen collected per year (Wille et al., 1985). However, the variety used in our study (MON 810) contains only small amounts of $\mathrm{Bt}$ toxin in the pollen and therefore a treatment was included where bees were fed purified Cry $1 \mathrm{Ab}$ toxin at a higher concentration, i.e. a 'worst case' scenario.

Other transgenic plants express protease inhibitors (PIs) which impair protein digestion of insects by inhibiting their digestive proteases (Laskowski and Kato, 1980). In contrast to Bt plants that are commercialised worldwide, PIexpressing transgenic plants are still at the experimental level. However, many plants have been successfully engineered and show resistance to a range of pest insects (Jouanin et al., 1998; Lawrence and Koundal, 2002). Honey bees possess serine-type protease digestive enzymes (Burgess et al., 1996) and are thus negatively affected if large quantities of the Kunitz soybean trypsin inhibitor (SBTI) are ingested (Malone and Pham-Delegue, 2001). This PI was therefore used in the present study.

In addition to measuring direct effects on hypopharyngeal gland development, we used ELISA and Western blot techniques to investigate whether this gland could take up ingested transgene products. The underlying hypothesis is that proteins present in the hypopharyngeal glands might be further transferred to the larval stages (Brodsgaard et al., 2003) which would have consequences for the exposure of honey bee larvae to transgene products.

\section{MATERIALS AND METHODS}

\subsection{Honey bee colonies}

For each replicate, we transferred a small queenright colony of c. 250 bees together with a single comb into a wooden cage of $14 \times 16 \times 4.5 \mathrm{~cm}$ (internal dimensions) with two glass sides. The comb contained eggs $<72 \mathrm{~h}$ old laid by the queen used in the 
experimental hive. Otherwise, the comb was free of pollen, nectar and older brood. The glass sides of the cages were covered with cardboard and each of the cages was put into a flight arena $(40 \times 35 \times 40 \mathrm{~cm}$ size) inside a climate chamber at $34 \pm 0.5^{\circ} \mathrm{C}, 60 \pm$ $5 \%$ relative humidity and a L15:D9 h light regime. Bees were free to leave the cage and fly inside the arena. In order to get experimental bees for the analysis of hypopharyngeal gland development, newly emerged adults from a large colony were colourcoded with correction fluid. For each replicate, 50 marked bees were randomly assigned to each of the cages at the start of the experiment. All bees used for one set of the experiment originated from the same standard hive. This setup allows direct access to brood, necessary to provide workers with a signal for development of the hypopharyngeal glands (Brouwers, 1983). Moreover, Lass and Crailsheim (1996) have shown that caged bees deprived of contact to the queen, older workers and brood, had smaller hypopharyngeal glands as compared to bees living in a colony. The experiment was terminated after 10 days when bees were removed for further analysis.

\subsection{Treatments}

Altogether, we had four treatments (Bt-pollen from Event MON810 maize; Bt toxin; SBTI low concentration and SBTI high concentration) and a control where bees were fed pollen from the nearisoline (non-transgenic) maize variety (Monumental) and pure 1:1 (w:v) sucrose solution. In all treatments, bees had access to sugar solution as a carbohydrate source, either with or without additives and maize pollen as a protein source from either the isoline or the transgenic plant. The first treatment used transgenic Bt-maize pollen originating from a field in southern Germany. Traces of Cry1Ab toxin was found in pollen although the concentration was below the quantification level of $5 \mathrm{ng} / \mathrm{g}$ dry weight in all of the six samples that were determined in our laboratory by ELISA (Anna Dutton, unpublished data). Pollen was collected by placing an individual inflorescence in a cellophane bag for $24 \mathrm{~h}$. Pollen was sieved to remove plant debris and subsequently stored at $-80{ }^{\circ} \mathrm{C}$ until required. For all other treatments and the control, pollen of the corresponding non-transformed maize variety (Monumental) was fed to the bees.

While pure sucrose solution was fed to bees of the control and the Bt pollen treatment, all other treatments received transgene products added to sucrose solutions. Lyophilised Cry1 $\mathrm{Ab}$ toxin, purchased from M. Carey (Dept. Biochemistry, Case Western Reserve University, Cleveland, OH, USA) was used for the second treatment. The amount of Bt-toxin fed to the honeybees was $360 \mu \mathrm{g} / 25 \mathrm{~mL}$ sucrose solu- tion/two days, corresponding to a $0.001 \%(\mathrm{w} / \mathrm{w})$ or $0.0014 \%(\mathrm{w} / \mathrm{v})$ solution. Based on personal observations honey bees consumed about 5-10 times more sugar solution than pollen, this concentration is estimated to be equivalent to pollen containing about $0.01 \%$ of the Bt toxin. Therefore, the concentration here is at least 10 times higher than that of maize events expressing the Bt toxin in the pollen such as Bt 176 (Koziel et al., 1993) and is congruent with a worst case scenario. The activity of the toxin when dissolved in a sucrose solution was proven for up to 48 hours in a bioassay with the target organism Ostrinia nubilalis using the same batch of toxin (Romeis et al., 2004). For the third and fourth treatment, the protease inhibitor, Kunitz soybean trypsin inhibitor SBTI (from Sigma-Aldrich, Buchs, Switzerland), was fed to bees as a $1 \%(\mathrm{w} / \mathrm{v})$ and a $0.1 \%$ $(w / v)$ sucrose solution. Based on observations of nectar and pollen consumption of honey bees, this is equivalent to a toxin concentration in the pollen of about 7.5 and $0.75 \%$. Though little information is available, McManus et al. (1994) found that plants can be protected from pests when protease inhibitors are expressed at c. $1 \%$ of total soluble leaf protein and thus the high concentration in the present study is again congruent with a worst case scenario.

Maize pollen ( $4 \mathrm{~g}$ in a petri dish) and sucrose solution ( $25 \mathrm{~mL}$ in a gravity feeder) was offered every other day on a pillar inside the arena. Remaining pollen was weighed on a microbalance and sucrose solution was quantified using a pipette. It should be noted, however, that both pollen and sucrose solution consumption included material that was stored in the comb. Dead bees were removed and counted also every other day. In order to test for effects on brood-rearing, we counted the number of sealed brood cells at the end of the experiment, i.e. after 10 days. Also after 10 days, all experimental bees were counted, frozen at liquid nitrogen and stored until further analysis at a temperature of $-80^{\circ} \mathrm{C}$. The experiment was repeated three times leading to a total of 15 colonies.

\subsection{Hypopharyngeal gland analysis}

Hypopharyngeal gland analysis was carried out upon 10 day-old hive bees. This due to the finding of Crailsheim et al. (1992) reporting acini diameters to be at a maximum in nine-day old bees, gland weight was reported to be highest in 12-day old bees (Fluri et al., 1982). Before dissecting the glands, the bees' heads were removed and weighed to the nearest $0.001 \mathrm{mg}$. This was done in order to conduct a regression analysis with gland weight and head weight and thus check whether head weight might be a good indicator for hypopharyngeal gland development. The hypopharyngeal glands were dissected in sodium chloride solution $(0.25 \mathrm{M})$ isotonic to the 
hemolymph (Hrassnigg and Crailsheim, 1998). For each treatment, we dissected 24 bees, eight from each colony. Acini diameter was measured with a microscope and an ocular micrometer at $62.5 \times$ magnification. For determination of hypopharyngeal gland weight, dissected glands were stored at $-80^{\circ} \mathrm{C}$, lyophilised for $48 \mathrm{~h}$, and weighed to the nearest $0.001 \mathrm{mg}$.

\subsection{Quantitative analysis of Bt-toxin and SBTI in hypopharyngeal glands}

Levels of the Bt-toxin (Cry1Ab) in hypopharyngeal glands were determined for control bees and those bees that were fed Bt pollen or Bt toxin, using a double sandwich ELISA kit (EnviroLogix Inc., Portland, Maine). Cry1 Ab standards at concentrations $0,0.5,2.5$, and $5 \mathrm{ppm}$. were used as calibrators. Spectrophotometric measurements were conducted with a microtiter plate reader (Dynatech MR 5000, Dynex Technologies, Ashford, UK) at $450 \mathrm{~nm}$ and data were analysed using the software package Biolinx 2.0 (Dynatech Laboratories Inc.) and Dynex Revelation G 3.2 (Dynex Technologies). In order to enhance the precision of the ELISA, we pooled 68 hypopharyngeal glands to analyse samples at a concentration of $4 \mathrm{mg}$ dry weight per $\mathrm{mL}$ of buffer. Meaning a total of three samples for each of the three treatments was analysed.

In order to detect SBTI in the glands, lyophilized gland samples were homogenised on ice in $50 \mu \mathrm{L}$ distilled water and centrifuged at $14000 \mathrm{~g}$ for $5 \mathrm{~min}$ at $4{ }^{\circ} \mathrm{C}$. Levels of total soluble protein were determined by Bradford assay, using BSA as standard. For immuno-assay by Western blotting, samples (containing $200 \mu \mathrm{g}$ total protein) were separated by electrophoresis on SDS-PAGE (12.5\% acrylamide minigels). Following electrophoresis, the proteins were transferred electrophoretically on to $0.45 \mu \mathrm{m}$ nitrocellulose. SBTI was detected by enhanced chemiluminescence (ECL) as previously described (Gatehouse et al., 1997), using polyclonal antibodies raised against SBTI as the primary antibody, with HRP-conjugated goat anti-rabbit IgG (BioRad) as the secondary antibody; purified SBTI from Sigma was used as a positive standard. Again, three samples were tested for each of the SBTI treatments together with two control samples.

\subsection{Statistical analysis}

Survival rates were compared among treatments with Kaplan-Meier survivorship analysis using the three colonies as replicates. Sucrose solution and pollen consumption rates were determined and corrected for survival by calculating the mean consumption per bee alive. Mean amount consumed during the whole experiment was compared using a one-way ANOVA with the treatments as factors and colonies as replicates. Differences among treatments in hypopharyngeal gland weight and acinus diameter were determined using a two-way ANOVA with experiment (colonies) and treatments as factors. Subsequently to both ANOVA's, Tukeys HSD test was applied to separate means. The relationship between weight of head and weight of hypopharyngeal glands was tested with regression analysis. All tests were conducted with the STATISTICA software (StatSoft, Inc., Tulsa).

\section{RESULTS}

At the end of the experiment, survival of experimental honey bees fed Bt pollen, Bt toxin or pure sugar solution (control) varied from 91.7 to $92.8 \%$ while $86.3 \%$ of bees fed $0.1 \%$ SBTI and $83.8 \%$ of bees fed $1 \%$ SBTI survived. Overall mortality was not significant after 10 days of the experiment, based on the three replicates $\left(\chi^{2}=8.35, \mathrm{df}=4, P=0.079\right)$.

Mean sucrose solution consumption was significantly different among treatments (ANOVA, $\left.\mathrm{F}_{4,10}=20.1, P<0.001\right)$. During the 10 days of the experiment, mean sucrose solution consumption per bee was $0.18 \mathrm{~mL}$ for the $1 \%$ SBTI treatment while 0.33 to $0.38 \mathrm{~mL}$ were consumed in the other four treatments. Thus, sucrose solution consumption was significantly reduced in the $1 \%$ SBTI treatment compared to all other treatments (Tukey-HSD test, $P<0.01)$. In contrast, pollen consumption of bees did not differ significantly among treatments during the course of the experiment $\left(F_{4,10}=0.20, P=0.93\right)$. The determination of the number of sealed brood cells at the end of the experiment revealed that virtually no offspring was reared in the $1 \%$ SBTI treatment (altogether three sealed brood cells) while 39140 sealed brood cells were found in all other treatments.

The hypopharyngeal gland development of ten-day-old honey bees differed significantly among treatments when the acinus diameter was used as the parameter (ANOVA, $\mathrm{F}_{4,105}=$ 5.91, $P<0.001)$. Acinus diameters were significantly smaller in the two treatments with SBTI compared to control bees which were fed untransformed pollen and pure sucrose solution (Tukey-HSD test, $P<0.01$, Fig. 1A). The experimental effect was significant $\left(\mathrm{F}_{2,105}=\right.$ $3.73, P=0.027$ ) but the interaction between 
A

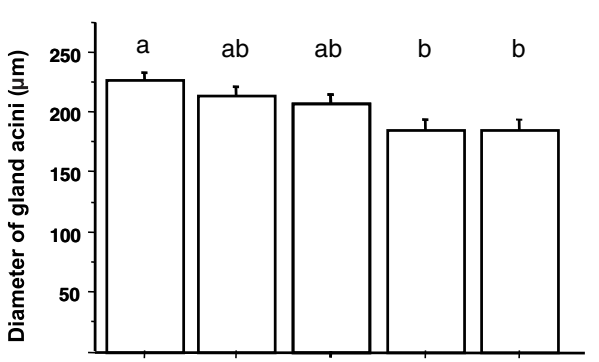

B

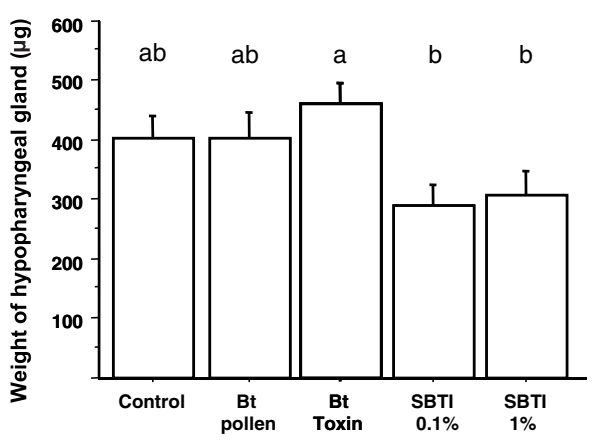

Figure 1. Development of hypopharyngeal glands of 10 days old honey bees fed with Bt-transgenic maize pollen (MON 810), Bt-toxin (Cry1Ab, $0.0014 \% \mathrm{w} / \mathrm{v}$ ), or Protease Inhibitor (SBTI, $0.1 \%$ and $1 \% \mathrm{w} / \mathrm{v})$, compared to a control treatment where bees were fed non-transgenic maize pollen and pure sugar solution. A: measurement of acini diameter, B: Dry weight of hypopharyngeal glands. Toxins were provided dissolved in a sugar solution. Given are means and standard errors, significant differences are indicated by different letters above the bars (ANOVA, Tukeys HSD test, $n=120$ ).

experiment and treatment was not $\left(\mathrm{F}_{8,105}=\right.$ $1.14, P=0.35)$. Significant differences were also found in the weight of hypopharyngeal glands among treatments $\left(\mathrm{F}_{4,105}=3.79 ; P<\right.$ 0.01 ; Fig. 1B). However, a significant effect was only observed when the hypopharyngeal gland weights of the two SBTI treatments were compared to the treatment with purified Bttoxin (Tukey-HSD test, $P<0.05$ ). There was again a significant experimental effect $\left(\mathrm{F}_{4,105}=6.19, P<0.01\right)$ but no interaction between experiment and treatment was found $\left(\mathrm{F}_{8,105}=0.91, P=0.52\right)$.

Head fresh weight was found to correlate positively with hypopharyngeal gland weight $\left(\mathrm{R}^{2}=0.35, \mathrm{~F}_{1,116}=61.4, P<0.001\right.$, Fig. 2$)$.

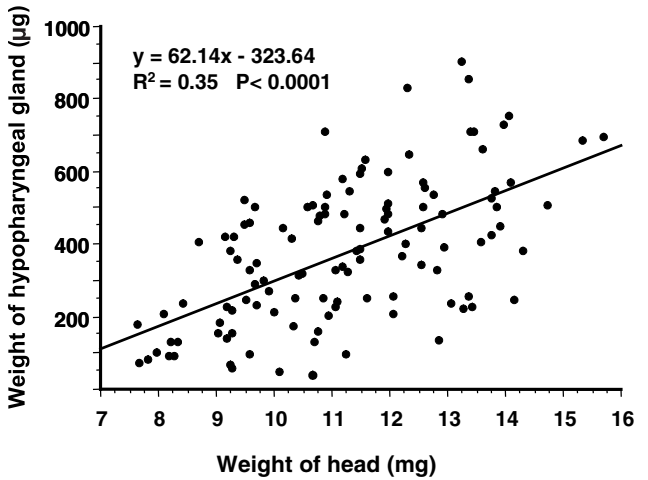

Figure 2. Relationship between dry weight of heads and the hypopharyngeal gland dry weight of 10 days old honeybees, fed with Bt-transgenic maize pollen (MON 810), Bt-toxin (Cry1Ab, $0.0014 \% \mathrm{w} / \mathrm{v}$, or Protease Inhibitor (SBTI) at $0.1 \%$ and $1 \% \mathrm{w} / \mathrm{v}$ or pure sugar solution as a Control (Regression Analysis, $\mathrm{n}=118$ ).

Since SBTI treatments affected the development of hypopharyngeal glands, we hypothesized that this may compromise the fit of the curve. However, when SBTI treated bees were excluded from the analysis, the correlation did not improve $\left(\mathrm{R}^{2}=0.36, \mathrm{~F}_{1,68}=39.3, P<0.001\right)$.

Quantitative analysis of the amount of Cry1 Ab present in the hypopharyngeal glands by ELISA revealed no detectable amount of toxin both in control bees and the bees fed with the Bt-maize pollen. Traces of Cry $1 \mathrm{Ab}$ that were below the quantification level were detected in the hypopharyngeal gland samples of bees fed the sugar solution containing $0.001 \%$ of Cry $1 \mathrm{Ab}$. To confirm this finding, three more samples were prepared from frozen bees using basically the same procedure. However, the glands were washed before the analysis to completely rule out any potential contamination. Qualitatively similar results were found, although in two of the samples the amount detected was even quantifiable $(0.25$ and $0.34 \mu \mathrm{g} / \mathrm{g}$ dry weight). In contrast, no SBTI protein was detected in any of the hypopharyngeal gland samples using Western blotting. The detection level was $9.6 \mu \mathrm{g} / \mathrm{g}$ dry weight.

\section{DISCUSSION}

Here we have shown that feeding honeybees the protease inhibitor SBTI for the first 10 days 
of adult life negatively affects the development of hypopharyngeal glands at the concentrations tested $(0.1 \%$ and $1 \%)$. Neither the Bt-pollen treatment nor the Bt toxin treatment affected hypopharyngeal gland development. This agrees with published results as, so far, negative effects of Bt-toxins on bees have not been reported (Malone and Pham-Delègue, 2001; Malone et al., 2004).

In contrast, SBTI fed to bees at a $0.1 \%$ or $1 \%$ concentration in sucrose solution is known to cause significant bee mortality (Malone et al., 1995; Burgess et al., 1996; Pham-Delègue et al., 2000). While the latter studies were mainly designed to study lethal effects over the lifetime of the bees, the aim of our study was to test for sublethal effects. Therefore the experiment was terminated after 10 days, i.e. before most of the mortality was observed in above mentioned studies.

In contrast, SBTI mixed into pollen food at a $1 \%$ concentration and provided to bees for the first seven days of adulthood only did not cause significant honey bee mortality (Malone et al., 1999). It should be noted though that bees consume considerably more nectar (sugar solution) than pollen, reducing the amount of toxin ingested in the latter study.

The effects of SBTI on bees were established in laboratory studies and should be related to more realistic field conditions. The high concentration used here and in other studies is very unlikely to be reached in the field and thus represents a worst case scenario. The lower concentration utilised in this study still relates to a high but more realistic quantity of the transgene product, assuming that these products are expressed in the pollen. In addition, it is important to take into account that bees under natural conditions would most probably not receive a continuous supply of protease inhibitor as they normally feed on a variety of pollen sources. However, this is clearly depending on geographic areas and the crop; for instance, oilseed rape or maize can be the dominating pollen source for several weeks.

The development of hypopharyngeal glands was studied with bees having direct access to brood over the whole period of 10 days. It has often been stated that access to brood is essential for the development of the hypopharyngeal glands (Brouwers, 1983; Moritz and Crailsheim, 1987; Lass and Crailsheim, 1996) but see Crailsheim and Stolberg (1989) who did not find an effect of brood rearing on gland development. The effect of transgene products on the development of hypopharyngeal glands with newly emerged bees kept in cages without a queen, older adults and brood was recently studied by Malone et al. (2004). They tested Cry $1 \mathrm{Ba}$, the biotin binding protein avidin and the serine-type protease inhibitor aprotinin. No negative effects of these transgene products were demonstrated in their study. In their bioassay, the glands increased in size, but not to the same extent as in the bees in our study or in those studies described above. The advantage of the assay without brood is that it is much easier to conduct, while the setup described here, which includes the rearing of brood, is closer to natural conditions. So far, it remains unclear which bioassay should be favoured if effects of novel plant protection products on hypopharyngeal glands are to be tested. One possibility to clarify this would be to include SBTI in the setup used by Malone et al. (2004).

Instead of dissecting bees, head weight of worker bees could be used as a measure of hypopharyngeal gland development as suggested by Hrassnigg and Crailsheim (1998). In contrast to their relatively high correlation rate of $82 \%$ our data showed a rather low correlation of $35 \%$. This difference may be due to experimental conditions, but until further investigation, measuring the size or weight of hypopharyngeal glands and not just head weight in order to determine an effect of transgene products on gland development may be advisable.

Bees that were fed with either $0.1 \%$ or $1 \%$ SBTI solution developed lighter hypopharyngeal glands than bees treated with Bt-toxin and had smaller acini than control bees. One factor that could contribute to the finding that there was no difference between lower and higher SBTI dose is that bees consumed significantly less sucrose solution in the $1 \%$ SBTI treatment compared to the other treatments. This might be due to a deterrent effect of SBTI on honeybees, however, the possibility can not be dismissed that less sugar solution was consumed due to a feed back mechanism, i.e. because bees were already affected by the toxin (e.g. show reduced activity levels). If bees were able to 
detect and consequently avoid the toxin under field conditions, this could have important implications for a risk assessment. Until now, no such deterrent effect has been detected in studies with honeybees fed transgene products, although it has been reported for other compounds such as alkaloids (Detzel and Wink, 1993).

To put these results in context, it must be noted that hypopharyngeal gland weight is about $100 \mu \mathrm{g}$ and acini diameter $80 \mu \mathrm{m}$ in newly emerged bees (Crailsheim and Stolberg, 1989; Deseyn and Billen, 2005). This indicates that, despite the observed differences, hypopharyngeal glands of bees treated with SBTI grew considerably during the experiment (see Fig. 1). An important question is whether the observed reduction in hypopharyngeal gland size has any effect for the colony? Studies by Maurizio (1954) suggested that nurse bees with smaller hypopharyngeal glands will be able to raise fewer offspring. Although this effect might be compensated for by a larger number of bees taking care for the larvae, it would of course be at the cost that fewer bees are available for other important duties such as foraging for pollen or nectar. In general, behavioural and physiological compensation mechanisms are possible but can be expected to entail costs for the whole bee colony. Therefore, detrimental effects by lower hypopharyngeal gland weight on honeybee colony performance can not be ruled out.

It has been stressed that long-term studies are needed if risks for honeybee colonies are to be assessed (Malone and Pham-Delègue, 2001). However, such studies are extremely labour- and cost intensive, especially if carried out with a sample size large enough to detect anything other than the very large effects. Therefore, assessment of indicators on potential long-term effects on colony development are needed. We believe that the hypopharyngeal glands of worker bees might be a good indicator to be measured in addition to bee mortality since they are of high importance for honeybee colony development. However, more research is necessary on the strength of the correlation between hypopharyngeal gland size and important colony parameters such as brood rearing.

In addition to effects on the development of hypopharyngeal glands, we also aimed to detect the ingested toxins in the glands. This is important knowledge for a complete risk assessment at the colony level because it has to include the larval stages which are being fed with large amounts of worker jelly produced by the glands. An earlier study has already tried to show the pathway of insecticides into larval food by using ${ }^{14} \mathrm{C}$ labeled material. Only traces of radioactivity could be detected in the hypopharyngeal glands while radioactivity was found to be largely confined to parts of the digestive system (Davis and Shuel, 1988). However, as the authors noted correctly, these traces of radioactivity in hypopharyngeal glands is no clear indication for the insecticide itself. In our study, we directly determined the levels of transgene products by using ELISA and Western Blot techniques. Small amounts of Bt toxin were indeed detected in the glands when bees were fed high concentrations of the toxin in the sucrose solution. However, this was about three orders of magnitude less than the amount originally fed to the bees. No SBTI could be found in the hypopharyngeal glands showing that these proteins are not transferred to the larval offspring via food produced in the glands, at least at the detection level set. Recently, Malone et al. (2004) did not detect any Cry1Ba, avidin or aprotinin in the hypopharyngeal glands after treatment for 10 days. The reasons for the different findings regarding the $\mathrm{Bt}$ toxin are unclear, however, one explanation may be that Malone et al. (2004) analysed single glands while we in the present study pooled 6-8 glands together, thereby increasing the detection level. The fact that the ELISA did detect Bt-toxin in the glands does not necessarily mean that it will enter the larval food or that the toxin is present in its active form. Based on the results of earlier studies on the production of worker jelly and its composition (e.g. Knecht and Kaatz, 1990; Santos et al., 2005), we conclude that transgene products are very unlikely to be transferred to honeybee offspring via hypopharyngeal glands or only in small amounts. Since pollen consumption of honeybee larvae is minimal as was recently shown by Babendreier et al. (2004), we conclude that the larval stages of the honeybee are far less exposed to transgene products when compared to the adults. 


\section{ACKNOWLEDGEMENTS}

We would like to thank H.U. Thomas (Zurich) for providing the bees and Louise Malone for her comments on an earlier version of the manuscript. The help of Lena Obrist and Heiri Klein with the ELISA analysis was very much appreciated. This study was funded by the Swiss Agency for the Environment, Forests and Landscapes, project number 810.3189.004.

Résumé - Influence de l'ingestion de pollen transgénique $B t$, de toxine $B t$ et de l'inhibiteur de protéase (SBTI) sur le développement des glandes hypoharyngiennes de l'Abeille domestique. Les glandes hypopharyngiennes des ouvrières d'abeilles (Apis mellifera L.) produisent la nourriture pour les larves et sont donc importantes pour le développement de la colonie. Nous avons étudié les effets de produits de transgène sur le développement des glandes hypopharyngiennes des ouvrières afin d'estimer le risque que représentent les cultures transgéniques pour les colonies d'abeilles.

L'expérimentation a été réalisée dans des chambres climatisées avec des colonies d' abeilles (A. mellifera) d'environ 250 individus maintenues en cages avec du couvain et une reine. Pour chaque traitement et chaque répétition, 50 abeilles fraîchement écloses étaient introduites dans les cages. Les abeilles témoins ont reçu du pollen de maïs non transformé et une solution de saccharose, les abeilles traitées du pollen de maïs trangénique $\mathrm{Bt}$ (MON810) ou une solution de saccharose comprenant soit de la toxine Bt purifiée (Cry1Ab, 0,0014\% poids/vol.), soit un inhibiteur de trypsine soja de Kunitz (SBTI) à deux concentrations différentes $(0,1 \%$ et $1 \%$ poids/vol.). $\mathrm{Ni}$ le pollen de maïs Bt, ni la toxine Bt n'a eu d' action sur la survie des abeilles ou sur le développement des glandes hypoharyngiennes après une période de nourrissement de $10 \mathrm{j}$. (Fig. 1A, B) Par contre les ouvrières fraîchement écloses et traitées au SBTI $(0,1 \%$ et $1 \%)$ durant $10 \mathrm{j}$ ont vu le poids moyen de leurs glandes hypopharyngiennes et le diamètre des acini (lobes des glandes) diminuer significativement (Fig. 1A, B). Le poids frais de la tête était corrélé positivement avec le poids des glandes hypoharyngiennes, mais l'on s'attendait à une relation plus forte (Fig. 2). A la concentration élevée (1\%), le SBTI a fait également baisser la quantité de solution de saccharose consommée et a inhibé virtuellement l'élevage du couvain : au total seules trois cellules de couvain operculé ont été observées lors du traitement au SBTI à $1 \%$ contre 39 à 140 cellules lors des autres traitements. Par contre, il n'y a pas eu de différence significative dans la consommation de pollen par les abeilles entre les différents traitements au cours de l'expérience. Alors qu'on a pu détecter par ELISA de petites quantités de toxine Bt dans les glandes hypoharyngiennes des abeilles nourries avec une solution de saccharose $+\mathrm{Bt}$, le buvardage de Western n'y a pas détecté de SBTI.
Il est dans l'ensemble très improbable que les produits de transgène soient transférés à la descendance via les glandes hypopharyngiennes ou alors ce ne serait qu'en petites quantités. Puisque la consommation de pollen par les larves d'abeilles est minime, nous concluons que les stades larvaires de l'Abeille domestique sont bien moins exposés aux produits de transgène que les adultes. Au total, la toxine Cry $1 \mathrm{Ab}$ exprimée dans le maïs transgénique Bt n'a provoqué aucun effet délétère chez les abeilles, tandis que la consommation de fortes quantités de SBTI a réduit le développement des glandes hypopharyngiennes. Si les plantes transgéniques exprimant le SBTI doivent poser un risque quelconque pour les abeilles, cela dépendra des quantités exprimées dans le pollen et le nectar et des mécanismes de compensation de la colonie d'abeilles.

Apis mellifera / Cry1Ab / inhibiteur de trypsine soja de Kunitz / plante transgénique / évaluation risque

Zusammenfassung - Der Einfluss der Aufnahme von Bt-transgenem Pollen, Bt-Toxin und Proteaseinhibitor (SBTI) auf die Entwicklung der Hypopharynxdrüsen der Honigbienen. Die Hypopharynxdrüsen der adulten Arbeiterinnen produzieren die Nahrung für die Larven und sind daher für die Entwicklung der Völker von hoher Bedeutung. Um die Risiken transgener Anbaupflanzen auf Bienenvölker abschätzen zu können, untersuchten wir daher die Auswirkungen transgener Erzeugnissen auf die Entwicklung der Hypopharynxdrüsen bei Arbeiterinnen. Wir führten ein Experiment in Klimakammern durch, in die wir Apis mellifera L. (Hymenoptera: Apidae) Völkchen mit etwa 250 Arbeiterinnen in Käfigen mit Brut und einer Königin einbrachten. Für jede Behandlung und Behandlungswiederholung wurden zusätzlich 50 frischgeschlüpfte Arbeiterinnen eingebracht. Die Kontrollbienen wurden mit nicht-transgenem Maispollen und Zuckerlösung gefüttert, während die Versuchsbienen Bt-transgenen Maispollen (MON 810) oder eine Zuckerlösung erhielten, die entweder gereinigtes Bt-Toxin (Cry1Ab, 0,0014 \% w/v) oder Kunitz Sojabohnen Trypsininhibitor (SBTI) in zwei Konzentrationen $(0,1 \%$ und $1 \% \mathrm{w} / \mathrm{v})$ enthielt Weder der Bt Maispollen noch das Bt-Toxin zeigten nach einer Fütterungszeit von 10 Tagen irgendwelche Auswirkungen auf das Überleben der Bienen oder die Entwicklung der Hypopharynxdrüsen (Abb. 1A, B). Im Gegensatz hierzu verminderte die Behandlung frischgeschlüpfter Bienen mit SBTI $(0,1$ und $1 \%)$ über 10 Tage das mittlere Gewicht der Hypopharynxdrüsen und den mittleren Durchmesser der Acini signifikant (Lobulas der Drüsen, Abb. 1A, B). Das Frischgewicht der Köpfe war mit dem Gewicht der Hypopharynxdrüsen positiv korreliert, obwohl die Beziehung weniger deutlich als erwartet war (Abb. 2). In der hohen Konzentration (1\%) verminderte SBTI auch die Menge der 
aufgenommenen Zuckerlösung und hemmte hierdurch die Brutaufzucht. Insgesamt wurden in der $1 \%$ SBTI Behandlung nur 3 verdeckelte Brutzellen gefunden, während dies in allen anderen Behandlungen zwischen 39 und 140 waren. Im Gegensatz hierzu unterschied sich die Pollenaufnahme während des Experiments nicht signifikant zwischen den Behandlungen.

Während mit ELISA geringe Mengen von Bt-Toxin in den Hypopharynxdrüsen der mit Bt-Zuckerlösung gefütterten Bienen zu finden waren, konnte SBTI nicht durch Western blotting in Drüsenproben ermittelt werden. Insgesamt ist die Übertragung der transgenen Produkte über die Hypopharynxdrüsen auf die Brut daher unwahrscheinlich oder sie werden nur in geringen Mengen übertragen. Da die Pollenaufnahme der Honigbienenlarven nur minimal ist, schliessen wir, dass die Larvenstadien der Honigbienen weit weniger den transgenen Produkten ausgesetzt sind als die Adulten.

Insgesamt zeigte damit das in dem Bt-transgenen Mais exprimierte Cry1Ab Toxin keine negativen Auswirkungen auf die Honigbienen, während der Verzehr hoher Mengen von SBTI die Entwicklung der Hypopharynxdrüsen beeinträchtigte. $\mathrm{Ob}$ damit die SBTI exprimierenden transgenen Pflanzen ein Risiko für Honigbienen darstellen, wird von den Mengen des im Pollen und Nektar exprimierten SBTI sowie möglichen kompensatorischen Mechanismen der Bienenvölker abhängen.

\section{Apis mellifera / Cry1Ab / Kunitz Sojabohnen Trypsininhibitor / transgene Pflanzen / Risikoabschätzung}

\section{REFERENCES}

Babendreier D., Kalberer N., Romeis J., Fluri P., Bigler F. (2004) Pollen consumption in honey bee larvae: a step forward in the risk assessment of transgenic plants, Apidologie 35, 293-300.

Baker H.G., Baker I. (1986) The occurrence and significance of amino acids in floral nectar, Plant Syst. Evol. 151, 175-186.

Brødsgaard H.F., Brødsgaard C.J., Hansen H., Lovei G.L. (2003) Environmental risk assessment of transgene products using honey bee (Apis mellifera) larvae, Apidologie 34, 139-145.

Brouwers E.V.M. (1983) Activation of the hypopharyngeal glands of honeybees in winter, J. Apic. Res. 22, 137-141.

Burgess E.P.J., Malone L.A., Christeller J.T. (1996) Effects of two proteinase inhibitors on the digestive enzymes and survival of honey bees (Apis mellifera), J. Insect Physiol. 42, 823-828.

Conner A.J., Glare T.R., Nap J.P. (2003) The release of genetically modified crops into the environment - Part II, Overview of ecological risk assessment, Plant J. 33, 19-46.

Crailsheim K. (1990) The protein balance of the honey bee worker, Apidologie 21, 417-429.
Crailsheim K., Stolberg E. (1989) Influence of diet, age and colony condition upon intestinal proteolytic activity and size of the hyopharyngeal glands in the honeybee (Apis mellifera L.), J. Insect Physiol. 35, 595-602.

Crailsheim K., Schneider L.H.W., Hrassnigg N., Bühlmann G., Brosch U., Gmeinbauer R., Schöffmann B. (1992) Pollen consumption and utilisation in worker honeybees: dependence on individual age and function, J. Insect Physiol. 38, 409-419.

Davis A.R., Shuel R.W. (1988) Distribution of ${ }^{14}$ Clabelled carbofuran and dimethoate in royal jelly, queen larvae and nurse honeybees. Apidologie 19, 37-50.

Deseyn J., Billen J. (2005) Age-dependent morphology and ultrastructure of the hypopharyngeal gland of Apis mellifera L. workers (Hymenoptera, Apidae), Apidologie 36, 49-57.

Detzel A., Wink M. (1993) Attraction, deterrence or intoxication of bees (Apis mellifera) by plant allelochemicals, Chemoecology 4, 8-18.

Dutton A., Romeis J., Bigler F. (2003) Assessing the risks of insect resistant transgenic plants on entomophagous arthropods: Bt-maize expressing Cry1Ab as a case study, BioControl 48, 611-636.

Fluri P., Lüscher M., Wille H., Gerig L. (1982) Changes in weight of the pharyngeal gland and haemolymph titres of juvenile hormone, protein and vitellogenin in worker honey bees, J. Insect Physiol. 28, 61-68.

Gatehouse A.M.R., Davison G.M., Newell C.A. (1997) Transgenic potato plants with enhanced resistance to the tomato moth, Laconobia oleracea: Growth room trials, Mol. Breed. 3, 4963.

Girard C., Picard-Nizou A.L., Grallien E., Zaccomer B., Jouanin L., Pham-Delègue M.H. (1998) Effects of proteinase inhibitor ingestion on survival, learning abilities and digestive proteinases of the honeybee, Transgenic Res. 7, 239-246.

Gupta P.R., Chandel R.S. (1995) Effects of Diflubenzuron and Penfluron on workers of Apis cerana-indica F. and Apis mellifera L., Apidologie 26, 3-10.

Haydak M.H. (1970) Honey bee nutrition, Annu. Rev. Entomol. 15, 143-156.

Hrassnigg N., Crailsheim K. (1998) Adaptation of hypopharyngeal gland development to the brood status of honeybee (Apis mellifera L.) colonies, J. Insect Physiol. 44, 929-939.

Jouanin L., Bonadé-Bottino M., Girard C., Morrot G., Giband M. (1998) Transgenic plants for insect resistance, Plant Sci. 131, 1-11.

Knecht D., Kaatz H.H. (1990) Patterns of larval food production by hypopharyngeal glands in adult worker honey bees, Apidologie 21, 457-468

Koziel M.G., Beland G.L., Bowman C., Carozzi N.B., Crenshaw R., Crossland L., Dawson H., Desai N., Hill M., Kadwell S., Launis K., Lewis K., Maddox D., McPherson K., Meghji M.R., Merlin E., Rhodes R., Warren G.W. Wright M., Evola S.V. (1993) Field performance of elite transgenic maize 
plants expressing an insecticidal protein derived from Bacillus thuringiensis, Biotechnology 11 , 194-200.

Laskowski M., Kato I. (1980) Protein inhibitors of proteinases, Annu. Rev. Biochem. 49, 593-626.

Lass A., Crailsheim K. (1996) Influence of age and caging upon protein metabolism, hypopharyngeal glands and trophallactic behavior in the honey bee (Apis mellifera L), Insectes Soc. 43, 347358.

Lawrence P.K., Koundal K.R. (2002) Plant protease inhibitors in control of phytophagous insects, Electr. J. Biotechn. 5, 122-138.

Malone L.A., Pham-Delègue M.H. (2001) Effects of transgene products on honey bees (Apis mellifera) and bumblebees (Bombus sp.), Apidologie 32, 287-304.

Malone L.A., Burgess E.P.J., Maxwell J.Z., Christeller J.T., William L.A. (1995) Toxicity of trypsin endopeptidase inhibitors to honey bees (Hymenoptera: Apidae), J. Econ. Entomol. 88, 46-50.

Malone L.A., Burgess E.P.J., Stefanovic D. (1999) Effects of Bacillus thuringiensis toxin, two Bacillus thuringiensis biopesticide formulations, and a soybean trypsin inhibiotor on honey bee (Apis mellifera L.) survival and food consumption, Apidologie 30, 465-473.

Malone L.A., Todd J.H., Burgess E.P.J., Christeller J.T. (2004) Development of hypopharyngeal glands in adult honey bees fed with a Bt toxin, a biotin binding protein and a protease inhibitor, Apidologie 35, 655-664.

Maurizio A. (1954) Pollenernährung und Lebensvorgänge bei der Honigbiene (Apis mellifera L.), Landwirtsch. Jahrb. Schweiz 62, 115-182.

McManus M.T., White D.W.R., McGregor P.G. (1994) Accumulation of a chymotrypsin inhibitor in transgenic tobacco can affect the growth of insect pests, Transgenic Res. 3, 50-58.

Moritz B., Crailsheim K. (1987) Physiology of protein digestion in the midgut of the honeybee (Apis mellifera L.), J. Insect Physiol. 33, 923931.

Pham-Delègue M.H., Girard C., Le Metayer M., Picard-Nizou A.L., Hennequet C., Pons O. Jouanin L. (2000) Long-term effects of soybean protease inhibitors on digestive enzymes, survival and learning abilities of honeybees, Entomol. Exp. Appl. 95, 21-29.

Picard-Nizou A.L., Grison R., Olsen L., Pioche C., Arnold G., Pham-Delègue M.H. (1997) Impact of proteins used in plant genetic engineering: Toxicity and behavioral study in the honeybee, $\mathbf{J}$. Econ. Entomol. 90, 1710-1716.

Romeis J., Dutton A., Bigler F. (2004) Bacillus thuringiensis toxin (Cry1Ab) has no direct effect on larvae of the green lacewing Chrysoperla carnea (Stephens) (Neuroptera: Chrysopidae), J. Insect Physiol. 50, 175-183.

Santos K.S., dos Santos L.D., Mendes M.A., de Souza B.M., Malaspina O., Palma M.S. (2005) Profiling the proteome complement of the secretion from hypopharyngeal gland of Africanized nursehoneybees (Apis mellifera L.), Insect Biochem. Mol. Biol. 35, 85-91.

Standifer L.N. (1967) A comparison of the protein quality of pollens for growth stimulation of the hypopharyngeal glands and longevity of honey bees, Apis mellifera L. (Hymenoptera: Apidae), Insects Soc. 14, 415-426.

Wille H., Wille M., Kilchenmann V., Imdorf A., Bühlmann G. (1985) Pollenernte und Massenwechsel von drei Apis mellifera Völkern auf demselben Bienenstand in zwei aufeinanderfolgenden Jahren, Rev. Suisse Zool. 92, 897-914. 